\title{
How many beds do we really need-for example, in neurosurgery?
}

One of the most important determinants of hospital usage is the level of available beds. Admission rates and efficiency of bed use are related to the number of available beds per 1000 catchment population; a high level of bed provision leads to patients staying in hospital for longer periods than necessary. ${ }^{1}$ So the determination of levels of bed provision is a key Health Service planning decision with important revenue implications, especially at a time of strict cash limits.

Faced with a fall in population and, therefore, under the Resource Allocation Working Party (RAWP), ${ }^{2}$ with a fall in funding for health services in London, the London Health Planning Consortium has attempted to examine critically the bed provision for acute services in general $^{3}$ and for various regional specialties including neurology and neurosurgery. ${ }^{4} \mathrm{~A}$ review $^{5}$ has recently been carried out in the Oxford Region of the neurosurgical service, known to be under extreme pressure, to assess among other things the required level of bed provision for this specialty. The results of these exercises, however, are appreciably different and a comparison of the two approaches shows that the implications for the allocation of resources are considerable.

Neurosurgical bed provision and use in England vary greatly. There is a fivefold difference in bed provision between the bestprovided region-Mersey-with 53 beds per million residents, and the worst-provided region-Oxford-with 11 . These differences, which are only slightly reduced if catchment populations are substituted for resident populations (table I),

TABLE I-Provision and use of neurosurgical beds by region, 1978

\begin{tabular}{lcccc}
\hline Region & $\begin{array}{c}\text { Beds/million } \\
\text { resident } \\
\text { population }\end{array}$ & $\begin{array}{c}\text { Beds/million } \\
\text { catchment } \\
\text { population }\end{array}$ & $\begin{array}{c}\text { Discharges and } \\
\text { deaths/ } \\
\text { available bed }\end{array}$ & $\begin{array}{c}\text { Duration } \\
\text { of stay } \\
\text { (days) }\end{array}$ \\
\hline Oxford & 11 & 11 & $38 \cdot 9$ & $8 \cdot 6$ \\
Wessex & 13 & 20 & 20.4 & 14.5 \\
Trent & 19 & 20 & $26 \cdot 1$ & $10 \cdot 9$ \\
West Midlands & 20 & 20 & $25 \cdot 1$ & $10 \cdot 7$ \\
Thames & 27 & 30 & $23 \cdot 0$ & 13.9 \\
East Anglia & 31 & 29 & $25 \cdot 4$ & $11 \cdot 8$ \\
South West & 32 & 27 & 32.0 & $8 \cdot 8$ \\
Yorkshire & 33 & 32 & $29 \cdot 0$ & $11 \cdot 7$ \\
North West & 34 & 33 & $20 \cdot 4$ & $14 \cdot 5$ \\
Northern & 43 & 44 & 16.8 & $15 \cdot 0$ \\
Mersey & 53 & 46 & 12.8 & 23.1 \\
\hline England & 28 & 27 & $22 \cdot 9$ & 12.9 \\
\hline
\end{tabular}

* Includes four Thames regions plus board of governors hospitals, aggregated because of substantial cross-boundary flows.

are reflected in the use of beds, the Oxford throughput being three times that of Mersey. The aggregated Thames regions' bed provision, including board of governors hospitals, of 27 beds per million residents is slightly below the overall value for England, while their throughput is at the national average level.

\section{Consortium's approach}

A catchment population for neurosurgery was calculated by allocating the population of the administrative areas of England

Oxford Regional Health Authority, Oxford OX3 7LF

G P A WINYARD, BM, MRCP, senior registrar in community medicine R H MCNEILLY, MD, FFCM, acting regional medical officer C B T ADAMS, MCHIR, FRCS, consultant neurosurgeon and Wales to different hospitals in proportion to the number of $\frac{O}{0}$ neurosurgical admissions from each area to each hospital. The total catchment population on this basis for the four Thames $\overrightarrow{\vec{F}}$ regions was estimated to be $15.3 \mathrm{~m}$, projected to decline to $15 \mathrm{~m}$ by 1988. Admission rates (standardised for age and sex) were projected forward to 1988 from Hospital Inpatient Inquiry $\frac{\bar{O}}{\bar{\omega}}$ (HIPE) data, and a figure of 660 admissions per million popula- $\overparen{\nabla}$ tion arrived at. Similar projections were made for duration of stay and turnover interval and the results compared with current $\%$ practice in hospitals in England. The lowest projected duration $\overrightarrow{0}$ of stay achieved by at least one hospital in three and the lowest turnover interval achieved by at least $40 \%$ of hospitals were $\vec{\omega}$ chosen. These figures are summarised in table II.

TABLE II-Current and projected bed usage data-London Health Planning Consortium

\begin{tabular}{lcccc}
\hline & $\begin{array}{c}\text { Admission } \\
\text { rates }\end{array}$ & $\begin{array}{c}\text { Duration } \\
\text { of stay } \\
\text { (days) }\end{array}$ & $\begin{array}{c}\text { Turnover } \\
\text { interval } \\
\text { (days) }\end{array}$ & $\begin{array}{c}\text { Beds per } \\
\text { million population }\end{array}$ \\
\hline 1977 (projected) & 635 & $14 \cdot 4$ & $1 \cdot 5$ & $29 \cdot 1$ (actual) \\
1988 (pron & 660 & $12 \cdot 7$ & $2 \cdot 0$ & $26 \cdot 5$ (projected)
\end{tabular}

After discussing other factors, such as medical and nursing staffing levels and the requirements for diagnostic and other support services that affect the size of a neurology and neurosurgery centre, the consortium recommended that a neurosurgical unit should serve a population of $1.5 \mathrm{~m}$ and should consist of 40 to 45 beds, a provision of 26.5 to 30 beds per million population. While the lower end of this suggested range of bed provision (26.5 beds/million) is the projected 1988 level of bed provision, the upper end ( $30 \mathrm{beds} / \mathrm{million}$ ) is equal to the present stock of neurosurgical beds related to the projected 1988 population. The implication is that the present levels of provision are largely correct, and the bulk of the report is concerned with the details of location of individual units.

\section{Oxford approach}

The catchment population of the Oxford unit was calculated in a similar manner and found to be $2.1 \mathrm{~m}$. This population in 1978 was served by a unit consisting of 21 adult beds and with access to paediatric surgical beds (on average three). This level $N$ of provision, which is 11.4 beds per million catchment population, was not regarded as adequate by either clinicians or the regional health authority. The high throughput and short duration of stay inevitably resulted in too early discharge of patients to home, to other hospital departments, and to other hospitals.

Furthermore, admissions had to be strictly controlled by intensive use of outpatient investigations and by careful selection of cases likely to benefit from neurosurgery. As a result of these policies the neurosurgical admission rate for the Oxford RHA population to all hospitals was 460 per million in 1978, compared with an overall rate of 675 per million for England.

After discussion with clinicians it was agreed that more beds were needed to permit an increase in duration of stay from just under eight days, which it had been for the previous four years, to 10 days, and to allow for more flexibility in admission policy. The translation of this flexibility, plus consideration of the impact of recent and imminent advances such as computer- 
assisted tomographic scanning and microsurgery, into an admission rate is bound to be arbitrary, and a value midway between current regional and national rates was suggestednamely, 560 per million. With the new duration of stay, and bed occupancy remaining constant at $88 \%$, this produced a bed requirement of 17.5 beds per million population. This means in effect a unit consisting of 36 adult beds for the Oxford catchment population, the provision for children remaining the same. This figure was thought to be adequate by the neurosurgical consultant staff, and extra beds are being opened as funds allow, the current position being 27 adult beds.

\section{Discussion}

Neither of these approaches to planning is ideal. Both combine some rational quantitative elements with informed but nevertheless arbitrary value judgments. Both were developed in response to specific local problems. In London there was a need to reduce services in the face of a declining population; in Oxford there was a need to augment an obviously pressurised service. What is striking is that the two attempts at rationally answering the same question "How many neurosurgical beds are needed ?" came up with such different answers: 17.5 beds per million population in Oxford and 26 to 30 per million population in London. The difference in resource terms in these two results is enormous. If the Oxford figure is applied nationally then England requires approximately 815 neurosurgical beds compared with the current $1300-$ a reduction of $35 \%$. The London Health Planning Consortium methodology, based on projections of national figures, will by definition recommend roughly the current levels of provision. Using the 1976-7 RAWP cost per case ( $£ 659$, updated to $1980-1$ levels producing $£ 1264$ per case), a neurosurgical bed with average throughput costs $£ 29000$ per year. On this basis, the savings nationally for a reduction to Oxford levels would be $£ 14 \mathrm{~m}$ per year. These results show the uneconomic cost implication of the present inadequate planning methods used in the National Health Service.

The most important questions are raised by the low neurosurgical admission rate that seems to result from low bed provision. What sort of patients were and are not being admitted in Oxford who are being admitted in other regions? Oxford admission rates may be compared with those available from published work, and, though diagnostic criteria are not strictly comparable, the admission rates seem to be similar (table III).

TABLE III-Comparison of neurosurgical rates for specific conditions

\begin{tabular}{|c|c|c|c|}
\hline Condition & Oxford & Other & \\
\hline \multicolumn{2}{|c|}{$\begin{array}{l}\text { Subarachnoid haemorrhage } \\
\text { reaching neurosurgical unit } 3 \cdot 7 / 100000\end{array}$} & $3 \cdot 2 / 100000$ & Surrey ${ }^{6}$ \\
\hline $\begin{array}{l}\text { Intracerebral aneurysm } \\
\text { treated by surgery }\end{array}$ & $3 \cdot 4 / 100000$ & $\left\{\begin{array}{l}4 \cdot 3 / 100000 \\
3 \cdot 6 / 100000\end{array}\right.$ & $\begin{array}{l}\text { USA }^{7} \\
\text { Ontario }^{8}\end{array}$ \\
\hline $\begin{array}{l}\text { Brain tumour requiring } \\
\text { surgery }\end{array}$ & $7 \cdot 8 / 100000$ & $\left\{\begin{array}{l}7 \cdot 1 / 100000 \\
9 \cdot 0 / 100000\end{array}\right.$ & $\begin{array}{l}\text { USA }^{7} \\
\text { Ontario }^{8}\end{array}$ \\
\hline
\end{tabular}

Similarly, averaging operation rates from HIPE for operations done largely by neurosurgeons does not show any substantial deficit for Oxford RHA residents (table IV).

An alternative explanation is that lack of neurosurgery beds is compensated for by extra provision in other specialties. Certainly the Oxford unit does not retain patients with head injury or patients requiring radiotherapy after their immediate postoperative spell. But the levels of neurology, trauma and orthopaedic, and radiotherapy beds in the Oxford Region are all below the national levels for these specialties so that direct substitution for lack of neurosurgical beds does not seem to be occurring (table V). Investigation and operation on patients in other specialty beds or an intermediate spell in a neurosurgical
TABLE IV-Number of operations per 100000 population per year*

\begin{tabular}{|c|c|c|c|}
\hline \multirow[b]{2}{*}{ Region } & \multicolumn{3}{|c|}{ Operation } \\
\hline & $\begin{array}{l}\text { Skull and } \\
\text { closed brain }\end{array}$ & $\begin{array}{c}\text { Excision of } \\
\text { intracranial } \\
\quad \text { lesion }\end{array}$ & $\begin{array}{c}\text { Other } \\
\text { intracranial } \\
\text { operations }\end{array}$ \\
\hline $\begin{array}{l}\text { Northern } \\
\text { Yorkshire } \\
\text { Trent } \\
\text { East Anglia } \\
\text { North-west Thames } \\
\text { North-east Thames } \\
\text { South-east Thames } \\
\text { South-west Thames } \\
\text { Wessex } \\
\text { Oxford } \\
\text { South Western } \\
\text { West Midlands } \\
\text { Mersey } \\
\text { North Western }\end{array}$ & $\begin{array}{l}11 \cdot 7 \\
12 \cdot 7 \\
11 \cdot 3 \\
14 \cdot 0 \\
14 \cdot 6 \\
12 \cdot 7 \\
11 \cdot 4 \\
10 \cdot 5 \\
11 \cdot 7 \\
10 \cdot 6 \\
12 \cdot 7 \\
16 \cdot 6 \\
13 \cdot 1 \\
10 \cdot 0\end{array}$ & $\begin{array}{l}1 \cdot 6 \\
2 \cdot 1 \\
3 \cdot 0 \\
2 \cdot 1 \\
2 \cdot 4 \\
2 \cdot 1 \\
1 \cdot 0 \\
5 \cdot 0 \\
1 \cdot 6 \\
2 \cdot 1 \\
3 \cdot 4 \\
2 \cdot 3 \\
0.3 \\
1 \cdot 8\end{array}$ & $\begin{array}{l}1 \cdot 6 \\
5 \cdot 9 \\
4 \cdot 0 \\
2 \cdot 4 \\
3 \cdot 1 \\
2 \cdot 2 \\
1 \cdot 8 \\
4 \cdot 3 \\
3 \cdot 2 \\
3 \cdot 8 \\
5 \cdot 4 \\
3 \cdot 2 \\
0.5 \\
3 \cdot 7\end{array}$ \\
\hline England & 12.5 & $2 \cdot 2$ & $3 \cdot 3$ \\
\hline
\end{tabular}

* Source: Hospital Inpatient Inquiry table 22 (ii). 1975 population estimates 1974, 1975, 1976 aggregated.

TABLE $\mathrm{v}-B e d$ provision in specialties closely related to neurosurgery, 1978

\begin{tabular}{lccc}
\hline & Neurology & Radiotherapy & Trauma and orthopaedic \\
\hline Oxford RHA & $0.03 / 1000$ & $0 \cdot 04 / 1000$ & $0.43 / 1000$ \\
England & $0.05 / 1000$ & $0.05 / 1000$ & $0.45 / 1000$
\end{tabular}

bed will raise the "neurosurgical admission" rate, but the extent of this is not available from current statistics. Taking this into account, the London Health Planning Consortium suggests that the overall neurosurgical "hospitalisation rate" is 750 per million but gives no basis for this assumption.

It is difficult to explain the vast difference in recommendations for neurosurgical bed provision on the basis of the available epidemiological and planning data. If an adequate level of service can be given from the much lower figure for bed provision recommended in Oxford, and there is no evidence that this is not so, then a review of the level of provision of neurosurgical services elsewhere is clearly needed. Comparison of these two approaches shows the inadequacy of present planning methods, but the resultant funding implications are of such importance that a national review of planning methods for small, defined specialties is urgently required. Potential revenue savings here are far greater than any that may be expected from the costsaving exercises that are currently absorbing so much NHS time and energy. Finally-and ironically-under RAWP money has been redistributed away from Oxford, which runs an efficient service from a small number of beds, to regions running less efficient services from too many beds.

\section{References}

1 Logan RFL, Ashley JSA, Klein RE, Robson DM. Dynamics of medical care. Memoir No 14. London: London School of Hygiene and Tropical Medicine, 1972.

${ }^{2}$ Department of Health and Social Security. Sharing resources for health in England. London: HMSO, 1976.

${ }^{3}$ London Health Planning Consortium. Acute hospital services in London. London: HMSO, 1979.

${ }^{4}$ London Health Planning Consortium. Report of the study group on neurology and neurosurgery. London: London Health Planning Consortium, 1980.

5 Oxford Regional Health Authority. Profile-Oxford neurosurgical service. Oxford: Oxford RHA, 1980.

${ }^{6}$ Crawford MD, Sarner M. Ruptured intracranial aneurysm-community study. Lancet 1965;ii:1254-7.

7 Glista GG, Miller RH, Kurland LT, Jereczek ML. Neurosurgical procedures in Olmstead County, Minnesota, 1970-4. I Neurosurg $1977 ; 46: 46-51$.

${ }^{8}$ Drake CG. Neurosurgery: considerations for strength and quality. $\mathcal{f}$ Neurosurg 1978;49:483-501.

(Accepted 17 December 1980) 